\title{
COMPETITION FOR SPACE BETWEEN FISHING AND EXPLORATORY OIL DRILLING, OBSERVED FROM A DRILLING PLATFORM IN THE ESPIRITO SANTO BASIN, SOUTHEASTERN BRAZIL
}

\author{
Alessandra Coutinho Thomé da Silva*, Jean Louis Valentin and Marcelo Vianna \\ Universidade Federal do Rio de Janeiro \\ Departamento de Biologia Marinha, CCS - Centro de Ciências da Saúde \\ (Bloco A, sala ss-054, 21949-900 Rio de Janeiro, RJ, Brasil) \\ *Corresponding author: alessandra.acts@globo.com
}

http://dx.doi.org/10.1590/S1679-87592015073306301

\begin{abstract}
A B S T R A C T
Fishing and oil drilling compete for space in some regions off the Brazilian coast. Fish congregate around drilling platforms, which attracts fishing vessels that may illegally breach the $500 \mathrm{~m}$ safety perimeter. The objective of this study was to identify the fleets that frequent the safety zone of a platform and their behavior and to determine if there was a seasonal relationship in this interaction, during two exploration campaigns, in different periods, carried out on the "Ocean Star" platform in the Espírito Santo Basin. The results indicated a high incidence of artisanal fishing vessels inside the prohibited area, and of uncooperative behavior on the part of the boat crews. The statistical method of Factorial Correspondence Analysis distinguished vessels that were using pelagic longlines to fish for dolphinfish, registered in the state of Espírito Santo and longer than $11 \mathrm{~m}$, which operated during the summer campaign. Vessels fishing for scombrids, which were less than $11 \mathrm{~m}$ long and registered outside Espírito Santo, were prominent in the autumn-winter campaign. In conclusion, the data showed that the fleets involved in each exploratory campaign were different, but to determine the real reason why the boats insist on frequenting the area close to the platform further study is necessary.
\end{abstract}

\section{RESUMO}

Atividades de pesca e perfuração exploratória disputam espaços em regiões oceânicas da costa brasileira. A agregação de peixes ao redor das plataformas atrai as embarcações para sua proximidade, fazendo com que adentrem a área de segurança de 500 metros, atividade considerada ilegal. Com o objetivo de identificar a frota que frequenta uma área de exclusão e a existência de relação sazonal nessa interação, foi realizado um estudo durante duas campanhas exploratórias, em períodos distintos, pela plataforma "Ocean Star" na bacia marítima do Espírito Santo. Os resultados indicaram uma elevada incidência de embarcações artesanais na área proibida e um comportamento não cooperativo por parte da tripulação. O método estatístico Análise Fatorial de Correspondência identificou embarcações que utilizavam o espinhel pelágico para pescaria de dourado (Coryphaena hippurus), registradas no Estado do Espírito Santo e com comprimento superiores a 11 $\mathrm{m}$, pertencentes à campanha realizada no verão. A pescaria de Scombridae, com embarcações menores do que $11 \mathrm{~m}$ e não registradas no Espírito Santo, foram identificadas na campanha realizada no outono-inverno. Em conclusão, pode-se afirmar que as frotas foram distintas em cada campanha exploratória, mas para comprovar o real motivo dessa aproximação da plataforma são necessárias mais pesquisas sobre o assunto.

Descriptors: Fishing, Petroleum drilling, Espírito Santo Ocean basin, Exclusion zone, Coryphaena hippurus.

Descritores: Pesca, Exploração de petróleo, Bacia marítima do Espírito Santo, Zona de exclusão, Coryphaena hippurus.

\section{INTRODUCTION}

Competition for space between different economic activities is often most intense in maritime settings. Off the southeastern coast of Brazil, the activities of drilling for oil and natural gas and fishing have given rise to numerous conflicts over ocean space, between the users of traditional open-sea 
fishing grounds and the oil companies that are intensely exploiting the same region.

Fishing and oil production compete for the allocation of marine territory and have a complex interaction, obligating fishermen and oil workers to coexist on the high seas (BRONZ, 2009). It was with the objective of guaranteeing the safety of navigation as well as that of the installations and structures, avoiding or reducing the probability of accidents caused by the interaction of fishing boats and oil platforms, that the principles recommended by international and national laws have been adopted in Brazil. It was then determined to create safety zones, covering an area of $500 \mathrm{~m}$ radius around each platform or emergent structure, from which vessels are excluded (UNCLOS, 1982; MARINHA DO BRASIL, 2000). The safety zones, even though they prohibit fishing operations, attract various fishing fleets because of the attraction the platforms hold for fish (JABLONSKI, 2008). This attractive effect makes it almost routine, even though illegal, for boats to fish in the areas where the oil platforms are located: the socalled "platform fishing" (BRONZ, 2009).

The oil-platform structures function as artificial habitats, attracting aggregations of different species of fish and leading to an increase in the diversity of the local ichthyofauna (FABI et al., 2004). The attraction of these structures for fish can be explained by the light or accoustic stimuli produced by the platforms' activities (JORGENSEN et al., 2002), by the need for the fish to orient themselves in the pelagic environment, and by the high density of prey associated with the structures (FABI et al., 2004). This aggregation results in an increase in fishery production. In the North Sea, catch rates rapidly increased closer to the platforms, indicating a local increase in the numbers of fish (LOKKEBORG et al., 2002). A study in the Indian Ocean indicated that the dolphinfish (Coryphaena hippurus) can be attracted by a structure at a distance of at least $820 \mathrm{~m}$ (GIRARD et al., 2007).

In Brazil, a study by JABLONSKI (2003), in the Campos Basin, state of Rio de Janeiro (RJ), showed that about $60 \%$ of the tuna landed in the state was caught in an area where many oil-drilling platforms are concentrated, and that catches made with lines and pelagic longlines by the fleet based in Macaé $(\mathrm{RJ})$, obtained in that area, comprised $12 \%$ of the total landed in this municipality. In another study, JABLONSKI (2008) found that some of the vessels that frequent the neighborhood of a platform installed in the Campos Basin came from the neighboring state of Espírito Santo, principally from Itaipava, and that in some cases these vessels operated within a distance of $10 \mathrm{~m}$ from the platform. MENEZES et al. (2010), working with the industrial fleet that fishes for the skipjack tuna (Katsuwonus pelamis) with rods and live bait in Rio de Janeiro, showed that historically, the strategy of fishing for optimum returns impels the vessels to fish near the oil platforms.

Although a few studies have examined the interaction of fishing with oil extraction activity, most of them limited to the Campos Basin of Rio de Janeiro, no information has been found as to which fleets are really responsible for this interaction, i.e., which vessels frequent the vicinity of offshore platforms. Consequently, the objective of this study was to identify which fishing fleet frequents the $500 \mathrm{~m}$ safety zone around a platform in the Espírito Santo Basin, the fishing boats' behavior while in the prohibited area, if there is any seasonal relationship, and to present suggestions that might minimize the conflict between these two important economic activities.

\section{Material and Methods}

Study Area

The study was carried out in the Espírito Santo Sedimentary Basin, $75 \mathrm{~km}$ offshore of Linhares, state of Espírito Santo. Four wells were drilled by the Ocean Star Semi-Submersible Platform in the course of two Exploration Campaigns (Fig. 1 and Table 1).

The first campaign corresponded to the exploratory drilling of the Moriche (1943'31.526"S; $\left.38^{\circ} 52^{\prime} 08.639^{\prime \prime} \mathrm{W}\right)$ and Guarapari wells (19³9'39.957'S; 3842'08.977'W), in Blocks BMES-37 and BM-ES-38 respectively, from 6 November 2011 to 25 February 2012. The second campaign involved the exploratory drilling of the Caju (19 $\left.56^{\prime} 45.87^{\prime \prime} \mathrm{S} ; 38^{\circ} 41^{\prime} 35.45^{\prime \prime} \mathrm{W}\right)$ and Dendê wells (20¹1'27.26''S; 38 39'40.44', W), in Blocks BM-ES39 and BM-ES-40 respectively, from 28 March 2013 to 10 August 2013.

\section{Data Collection}

This study collected the data obtained as part of the Social Communication Project (SCP), during two exploration campaigns conducted by the company Perenco Petróleo e Gás do Brasil Ltda. The SCP provides information about the characteristics of an activity, and where and when it occurs. This Project is part of the request for an environmental permit for an Operating License, imposed by the environmental agency (CGPEG/IBAMA) on oil and gas companies. According to Bronz (2009), this type of project is undertaken so that fishermen may be informed of the operations and not pass through areas where they would be subject to fines. 




Fig. 1. Locations of the wells drilled during the First Campaign (Moriche and Guarapari) and Second Campaign (Caju and Dendê), in the Espírito Santo Basin, southeastern Brazil.

Table 1. Monitoring period during the exploration campaigns in the Espírito Santo Basin, southeastern Brazil. The time interval between wells represents the period during which the drilling platform was being moved.

\begin{tabular}{|c|c|c|c|c|c|c|c|c|}
\hline \multirow{3}{*}{$\begin{array}{l}\text { Exploration } \\
\text { Campaigns }\end{array}$} & Start & End & Start & End & Start & End & Start & End \\
\hline & $6 \mathrm{Nov}$ & $24 \mathrm{Dec}$ & 27 Dec & $25 \mathrm{Feb}$ & $28 \mathrm{Mar}$ & 28 Jun & $2 \mathrm{Jul}$ & 10 Aug \\
\hline & 2011 & 2011 & 2011 & 2012 & 2013 & 2013 & 2013 & 2013 \\
\hline First & \multicolumn{2}{|c|}{ Moriche Well } & \multicolumn{2}{|c|}{ Guarapari Well } & \multirow{2}{*}{\multicolumn{2}{|c|}{ Caju Well }} & \multirow{2}{*}{\multicolumn{2}{|c|}{ Dendê Well }} \\
\hline Second & & & & & & & & \\
\hline
\end{tabular}

The environmental technicians, embarked on the drilling platform, were responsible for collecting data in the field. Upon sighting a fishing vessel within the $500 \mathrm{~m}$ safety zone around the platform, the technician was responsible for noting the main characteristics of the vessel, including the name, registration number, length $(\mathrm{m})$, time(s) of day when the record was made $(\mathrm{h})$, distance from the platform (m) and the activity of the vessel at the time of sighting. The Fishing Vessel Record Form was then completed and a photographic record of the vessel was attached to it. Next, the environmental technician attempted to contact the crew of the vessel by VHF radio. If the attempt was successful, certain information was requested: location of embarkation and disembarkation, municipality where the vessel was registered, entity with which the vessel is associated, fishing gear used, main species caught, and engine horsepower (HP). After these data were obtained, the crew was informed of the prohibition against sailing within the safety zone and the boat was requested to move farther away. All these data were tabulated for each exploration campaign, and any missing information was noted.

\section{Data Analysis}

A list of the names and registration numbers of the vessels identified was sent to the Ministry of Fisheries and Aquaculture so that the field data could be compared with the official data, and whenever 
possible, the missing data obtained. The Ministry added further information about the vessels, such as the unit of the Federation where they were registered, length, type of fishing license, and registration number of each vessel. If the boat's length estimated by the environmental technician differed from the official length provided by the Ministry, the official size was used in the analysis.

The percentages of data including the number of vessels sighted on each campaign and during the two stages of exploratory drilling were calculated. Then the records in which all the variables for each vessel and its fishing activities were registered were analyzed together using the technique of Factorial Correspondence Analysis. After the first groups were separated, a second analysis was conducted, excluding those records from the second campaign that contributed strongly to the inertia of axis 1, masking the relationships among other variables. For the Factorial Correspondence Analysis, the data were transformed into a binary file, including: Exploration Campaign (First or Second), number of vessels sighted $(\mathrm{n}=1$ or $\mathrm{n}>1)$, time period during which the vessel remained inside the safety zone (1 or 2 periods), length of the vessel $(>=11 \mathrm{~m}$ or $<11 \mathrm{~m})$, activity being carried out when the boat's presence was recorded (fishing or other), type of fishing license (dolphinfish - horizontal longline or other), VHF call (whether or not the crew responded), distance from the platform $(<=20 \mathrm{~m}$ or $>20 \mathrm{~m})$, location where the vessel was registered (Espírito Santo or outside Espírito Santo) and registration with the Ministry (vessel registered or not). When the vessel's registration number was not obtained, the location where the vessel was registered and the registration with the Ministry were considered "not determined".

\section{Results}

During the 110 days of the First Exploration Campaign, 80 recordings of fishing boats within the safety area of the platform were made (mean 0.7 recordings/day). In the Second Campaign, totaling 133 days, 112 vessels were sighted (mean 0.9 recordings/day). On the two campaigns, a total of 192 vessels were sighted around the platform. The results obtained are shown in Table 2.

Attempts to communicate with the boat crews via VHF radio were unsuccessful in $96.3 \%$ of the total number of cases, on both campaigns. Only four attempts succeeded completely in the First Campaign, and three in the Second. The majority of vessels were observed to be fishing $(77.6 \%)$, within the $500 \mathrm{~m}$ radius around the platform, during both campaigns. In 20 and 22 recordings on the First and Second Campaigns respectively, the vessels observed were not fishing, but were sailing or anchored. In only one case on the First Campaign was it impossible to identify the activity being carried out by the vessel at the time of recording.

Table 2. Percentage of each variable, for the fishing vessels sighted within the platform exclusion zone on the First Campaign $(n=80)$, Second Campaign $(n=112)$ and total $(n=192)$, in the Espírito Santo Basin, southeastern Brazil.

\begin{tabular}{lllllll}
\hline \hline Variables & \multicolumn{2}{c}{$\begin{array}{c}\text { First } \\
\text { Campaign }\end{array}$} & \multicolumn{2}{c}{$\begin{array}{c}\text { Second } \\
\text { Campaign }\end{array}$} & Total \\
\cline { 2 - 7 } & $\mathrm{n}$ & $\%$ & $\mathrm{n}$ & $\%$ & $\mathrm{n}$ & $\%$ \\
\hline Recordings & 80 & 100 & 112 & 100 & 192 & 100 \\
1 vessel sighted & 69 & 86.2 & 92 & 82.1 & 161 & 83.8 \\
2 or more vessels sighted & 11 & 13.7 & 20 & 17.9 & 31 & 13.5 \\
1 period remaining near platform & 44 & 55.0 & 49 & 43.7 & 93 & 48.4 \\
2 periods remaining near platform & 36 & 45.0 & 63 & 56.2 & 99 & 51.6 \\
Vessel length >= 11 m & 66 & 82.5 & 91 & 81.2 & 157 & 81.8 \\
Vessel length < 11 m & 1 & 1.2 & 10 & 8.9 & 11 & 5.7 \\
Vessel length not determined & 13 & 16.2 & 11 & 9.8 & 24 & 12.5 \\
Registered in Espírito Santo & 73 & 91.2 & 99 & 88.4 & 172 & 89.6 \\
Registered outside Espírito Santo & 2 & 2.5 & 4 & 3.6 & 6 & 3.1 \\
Registration locale not determined & 5 & 6.2 & 9 & 8.0 & 14 & 7.3 \\
Activity carried out: fishing & 59 & 73.7 & 90 & 80.4 & 149 & 77.6 \\
Other activity & 20 & 25.0 & 22 & 19.6 & 42 & 21.9 \\
Activity not identified & 1 & 1.2 & 0 & 0.0 & 1 & 0.5 \\
License: Dolfinfish - horizontal longline & 42 & 52.5 & 77 & 68.7 & 119 & 62.0 \\
Other license & 21 & 26.2 & 21 & 18.7 & 42 & 21.9 \\
License not determined & 18 & 22.5 & 14 & 12.5 & 32 & 16.7 \\
Responded to VHF call & 4 & 5.0 & 3 & 2.7 & 7 & 3.6 \\
Did not respond to VHF call & 76 & 95.0 & 109 & 97.3 & 185 & 96.3 \\
MPA registration & 62 & 77.5 & 98 & 87.5 & 160 & 83.3 \\
No MPA registration & 13 & 16.2 & 6 & 5.4 & 19 & 9.9 \\
MPA registration not determined & 5 & 6.2 & 8 & 7.1 & 13 & 6.8 \\
Distance from platform <= 20 m & 22 & 27.5 & 35 & 31.2 & 57 & 29.7 \\
Distance from platform > 20 m & 58 & 72.5 & 77 & 68.7 & 135 & 70.3 \\
\hline
\end{tabular}


In 160 recordings or $83.3 \%$ of the vessels sighted on one or other campaign, the vessels were registered with the Ministry of Fisheries and Aquaculture. However, in some cases $(6.8 \%)$ it was not possible to confirm the vessel's registration. Because this information was obtained visually, the environmental technician may have had difficulty in obtaining the name and/or registration number of the vessels sighted. In some cases, this difficulty was due to the greater distance of the vessel from the platform, or because the vessel's presence was recorded at night. In other cases, even with the vessel close to the platform, it was not possible to obtain the data because they had been erased or covered or were missing from the vessel's hull. On the First Campaign, 13 vessels were sighted near the drilling rig $(16.2 \%)$, with no Ministry registration determined. On the Second Campaign, this number fell to six (5.4\%). In $89.6 \%$ of the cases in both campaigns, the vessel was registered in some municipality of the state of Espírito Santo.

Considering both campaigns, $62 \%$ of the vessels sighted possessed a licence to fish for dolfinfish ( $C$. hippurus) using a horizontal surface longline (with live bait). This type of fishing licence was observed on vessels close to the platform in 42 recordings made on the First Campaign (52.5\%) and 77 on the Second Campaign $(68.7 \%)$. In $26.2 \%$ and $18.7 \%$, respectively, of the recordings made on the first and second campaigns, the vessels observed possessed some other type of fishing licence, such as, for example, for swordfish (Xiphias gladius), using a horizontal surface longline, or skipjack tuna ( $K$. pelamis), using a rod and line (with live bait). For vessels with an undetermined registration number, it was not possible to determine the fishing license. The vessels not registered with the Ministry of Fisheries and Aquaculture did not possess a fishing licence. In both cases, the licence was designated "not determined".

Vessels $11 \mathrm{~m}$ or longer were observed in $81.8 \%$ of the recordings. In $12.5 \%$ of the cases, it was not possible to determine the length of the vessel, and only $5.7 \%$ of the cases related to vessels less than 11 $\mathrm{m}$ long. The largest vessel sighted was $14.5 \mathrm{~m}$ long.

The great majority of the recordings $(83.8 \%)$ of fishing boats within the $500 \mathrm{~m}$ safety zone reported a single vessel. On the First Campaign, $13.7 \%$ and on the Second, $17.9 \%$ of the recordings concerned more than one vessel within the prohibited zone. In these cases, the vessels interacted with each other, normally tied one to another while one vessel was moored to the platform for protection from bad weather.

Many vessels remained in the safety zone of the platform for more than one period (morning and afternoon) without leaving the prohibited area, or then returned after a period outside it. In $45 \%$ of the cases recorded on the First Campaign, the vessels were recorded as being within the $500 \mathrm{~m}$ area for two periods. During the Second Campaign, this percentage increased to $56.2 \%$. In the First and Second Campaigns, $27.5 \%$ and $31.2 \%$ of the records were, respectively, of vessels that came within $20 \mathrm{~m}$ of the platform.

Of the 80 recordings made during the First Campaign, 31 different vessels could be identified. Sixteen of these entered the prohibited area twice or more $(51.6 \%)$. On the Second Campaign, 34 vessels were recorded, 22 of which returned at least once to the safety zone during the campaign $(64.7 \%)$. Of the 56 vessels recorded, nine were identified during both campaigns, and five of these were sighted more than once in both campaigns (Table 3 ).

Table 3. Percentage of fishing vessels sighted more than once in the platform exclusion zone, observed during the First Campaign $(\mathrm{n}=31)$, Second Campaign $(\mathrm{n}=34)$ and on both campaigns $(n=9)$ in the Espírito Santo Basin, southeastern Brazil.

\begin{tabular}{lcccccc}
\hline \hline Vessels & \multicolumn{2}{c}{$\begin{array}{c}\text { First } \\
\text { Campaign }\end{array}$} & \multicolumn{2}{c}{$\begin{array}{c}\text { First } \\
\text { Campaign }\end{array}$} & \multicolumn{2}{c}{$\begin{array}{c}\text { Both } \\
\text { campaigns }\end{array}$} \\
\cline { 2 - 7 } & $\mathrm{N}$ & $\%$ & $\mathrm{~N}$ & $\%$ & $\mathrm{n}$ & $\%$ \\
\hline Identified & 31 & 100 & 34 & 100 & 9 & 100 \\
Sighted more & 16 & 51.6 & 22 & 64.7 & 5 & 55.6
\end{tabular}

than once

For 167 vessels sighted, all the variables were known and were evaluated by Factorial Correspondence Analysis (Fig. 2). The first dimension (axis 1) of the factorial analysis identified three variables responsible for $20 \%$ of the inertia of the data, with strongly positive coordinates on the axis. The variables characterized vessels registered outside Espírito Santo (Registry Outside ES), with length less than $11 \mathrm{~m}($ Length $<11)$ and not registered with the Ministry of Fisheries and Aquaculture ( noMPA). They were observed only during the second campaign, very close to the platform $($ Dist $<=20)$ and were recorded as fishing during two separate periods (2periods). These last two variables also showed positive coordinates on this axis, although with lower values. Also, these vessels possessed another type of fishing licence than that for dolphinfish (Other License).

Another factor of the analysis (second dimension, explaining $16.7 \%$ of the inertia) is linked mainly to the duration of fishing and to the distance from the platform. Thus, with strongly negative coordinates on axis 2 , the variables identified a longer duration of fishing (2periods) and closer to the platform $($ Dist $<=20)$. These were vessels registered in 
Espírito Santo, with differing lengths, and were fishing for dolphinfish. In contrast, variables that characterized other activities (OtherActiv), of shorter duration (1period) and farther from the platform (Dist $>20 m$ ) showed positive coordinates on axis 2 . These activities were independent of the size of the boat.

For the second analysis, seven records from the Second Campaign were excluded, leaving data for 160 observations. The results of this analysis (Fig. 3) highlighted, in decreasingly negative coordinates along the first axis (18.9\% of inertia), the variables that characterized vessels from outside Espírito Santo (RegistryOutsideES), that were not registered with the MPA (noMPA), that responded to the VHF call (VHFyes), were licensed for fish other than dolphinfish (OtherLicense, during only one sighting period (1period) and at a distance from the platform greater than $20 \mathrm{~m}$ (Dist>20m). This type of recording occurred mainly on the First Campaign (Campaign1). The second factorial axis (15.9\% of inertia) distinguished some vessels that were small (Length $<11$ ), performing non-fishing activities (OtherActiv), farther from the platform (Dist $>20 m$ ), registered in Espírito Santo (RegistryES), registered with the MPA (yesMPA) and did not respond to a VHF call (VHFno).

\section{DisCUSSION}

In contrast to the effects of reduction and subsequent diversification of the benthic macrofauna that are observed after one and two years following the installation of an oil platform (MANOUKIAN et al., 2010), a platform's effect on the fishery is immediately apparent. The aggregation effect of large pelagic fishes by the platform monitored here, which then attracted fishing vessels, could be observed within the first days after it had been installed. This behavior coincides with the results of JABLONSKI (2008), who analyzed the aggregation effect on fish around a platform in the Campos Basin (RJ) soon after it had been installed. Almost no time interval was necessary for this effect to be evident. However, the mean number of recordings of vessels per day found in this study in the Espírito Santo Basin (ES) was more than double that reported by JABLONSKI (2008) in the first two stages of his study $(0.3$ and 0.4$)$ in the Campos Basin. Only the findings in the third stage were similar (0.8), and this stage was of shorter duration. This difference probably stems from the greater proximity of the platform monitored in this study to the home port. In both cases, boats from Espírito Santo were identified as practitioners of socalled "platform fishing".

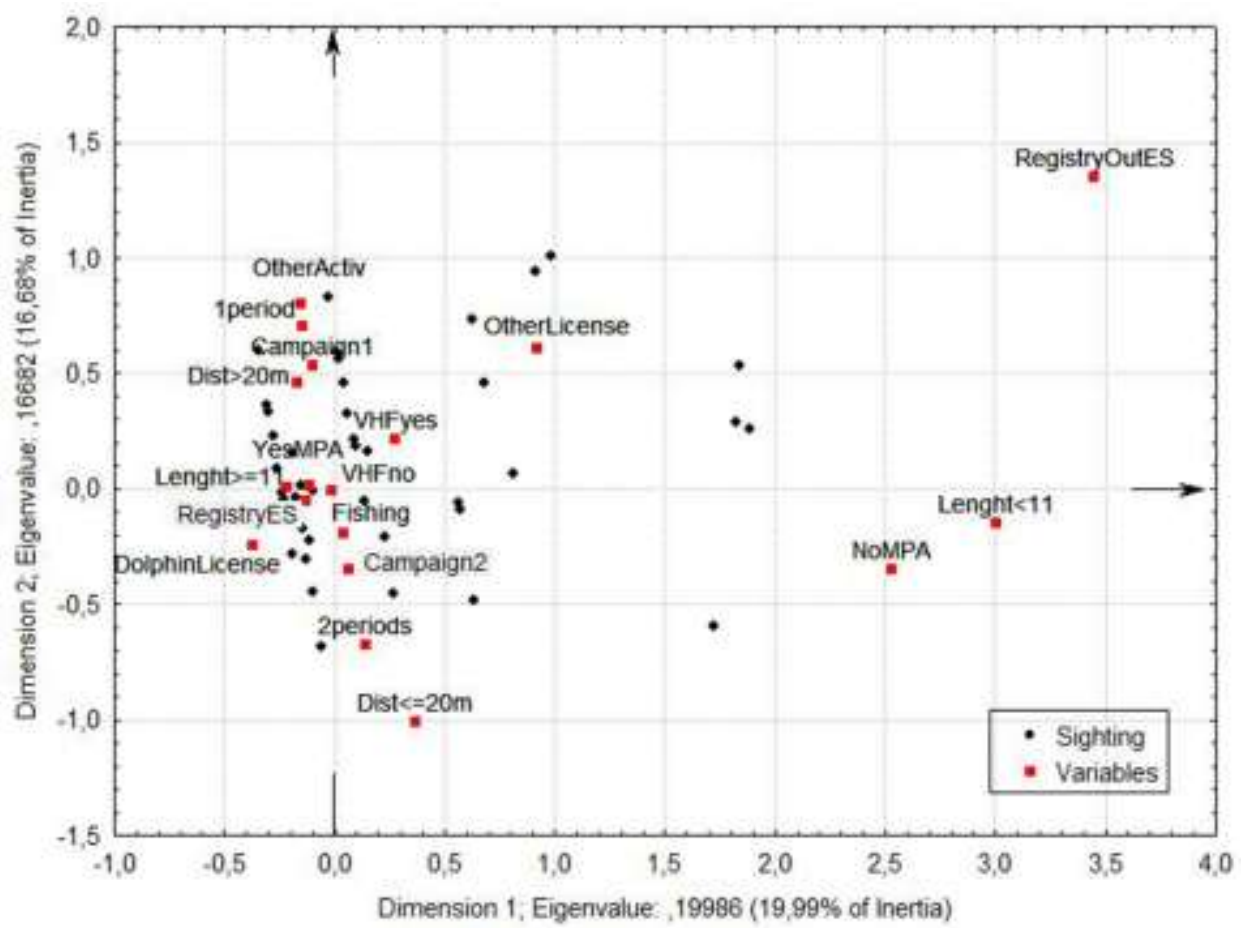

Fig. 2. Factorial correspondence analysis. Projection of the fishing vessels sighted within the platform exclusion zone and of the variables on factorial plane 1-2, in the Espírito Santo Basin, southeastern Brazil. 




Fig. 3. Factorial correspondence analysis. Projection of fishing vessels sighted in the platform exclusion zone and of the variables on factorial planes 1-2 (excluding seven records made during the Second Exploration Campaign), in the Espírito Santo Basin, southeastern Brazil.

The behavior of concealing a vessel's identification mentioned by JABLONSKI (2008) and also present during our campaigns, shows that many fishermen are aware that they are acting illegally in entering the safety zone around the drilling platforms. The company responsible for the platform must report any vessel remaining in the exclusion zone to the Port Authority, but it is necessary to provide the name and registration number of the boat. Aware of their offense and afraid of being fined, the crew members conceal their identification.

Knowledge of their transgression on the part of the fishing fleet is corroborated by the low percentage of boat crews that cooperated with the observers, i.e., entered into conversation and provided the information needed for the study; only a very small number responded to the VHF call. In the study by Jablonski (2008), the proportion of responses was much higher than in the present study. This difference may be due to the fact that in the present study, the environmental technicians were stationed on the drilling platform. In contrast, the observers in the study by JABLONSKI (2008) were aboard a support vessel, which facilitated communication with the crews. Having a fisherman aboard as an observer, as was done by JABLONSKI (2008), may also have encouraged the fishing boat crews to cooperate, because this permitted a more informal dialogue and greater confidence in providing the required information.

According to MARTINS and DOXSEY (2006), if we use the criterion of size, we can classify the fleet identified as being composed mainly of artisanal fishing boats from Espírito Santo, since the majority of the recordings were of vessels up to $12 \mathrm{~m}$ long. Closer analysis shows that most of the vessels were between 11 and $14.5 \mathrm{~m}$. JABLONSKI (2008) observed only three vessels in more than one stage, whereas in this study nine vessels were sighted on both campaigns. Five vessels were sighted more than once on the First Campaign, and repeated their behavior during the Second. These recurrent visits to a particular offshore area confirm that good catches were obtained around the platform. The farther a vessel travels from the coast, the higher the cost of fishing, due to the increase in hours worked and the greater fuel expense (MARTINS; BRAGA, 2009).

The group distinguished in the first factorial correspondence analysis consisted of vessels sighted during the Second Exploration Campaign, between the months of March and August 2013. This period coincides with the largest catches of skipjack tuna $(K$. 
pelamis), by the fleet using rods and live bait, from Rio de Janeiro, which also conducts platform fishing in the Campos Basin (MENEZES et al., 2010). However, according to SILVA and SOARES (2013), off the coast of Espírito Santo, March and August are also months of large catches of skipjack tuna, in addition to November. The most prominent group in the first analysis consisted of vessels from outside Espírito Santo and which had a fishing license other than for dolphinfish (C. hippurus) using a pelagic longline. The main targeted species for handline fishery on the eastern coast of Brazil (KLIPPEL et al., 2005). This result suggests that the fishing carried out during the Second Campaign may have targeted scombrids, such as $K$. pelamis, since the dolfinfish is targeted by the fleets from Vitória and Itapemirim at another time of year (MARTINS; DOXSEY, 2006). The second correspondence analysis grouped the vessels recorded during the First Campaign. This period between November and February was mentioned by JABLONSKI (2003) and KLIPPEL et al. (2005) as the best season of the year to catch dolfinfish with a pelagic longline. MARTINS et al. (2005) and MARTINS and DOXSEY (2006) stated that the fleets from Vitória and Itapemirim, due to the seasonal character of catching dolfinfish, target this species during summer. SILVA and SOARES (2013), monitoring the fishery landings in Espírito Santo, showed that the harvest period for dolfinfish and the greatest use of pelagic longlines coincided with the period of the First Exploration Campaign in the present study.

As in any situation where different users compete spatially for the use of natural resources, conflicts resulting from any restrictions and impacts imposed on stakeholders are becoming common in marine and coastal zones (JABLONSKI, 2003). Fishing and the oil production chain in Brazil are the two main activities that extract resources from undersea areas. The conflict between these activities stems from their need to make use of the same geographical space (MARTINS; BRAGA, 2009). The aggregation effect of the platforms on fish leads these vessels to deviate from their natural routes to the waters close to the structures. Consequently the fishing vessels are also attracted to the neighborhood of the platforms, which means that the oil vs. fishing conflict will continue. In order to minimize this conflict it is necessary to improve communications with the fishing community affected by the oil exploration and production activities. The $500 \mathrm{~m}$ radius around the platform needs to be understood by the fishermen as a necessary distance to avoid accidents. However, the concentration of fish near the platform makes it very attractive to the fisherman, who then ceases to exercise due regard for his own safety or that of the platform.
The safety zones around the platforms are small protected areas where many species of fish, at different life stages, can have a better chance to survive and gain biomass (FABI et al., 2004). However, according to JABLONSKI (2008), fishermen are attracted by the enhanced fishing in the general area around the platform, not only in the 500 $\mathrm{m}$ safety zone. The approach to the fishing community must, therefore, emphasize the advantages of respecting the safety area, where fishing is prohibited. Thus, the oil $v s$. fishing conflict could be reduced and these activities could use the ocean space in a more peaceful manner. However, we observed that the drilling rig was operating in the area precisely during the season when the dolphinfish, an important fishery resource, is present in greatest abundance. As this fish is seasonal and the harvest occurs over a short period, the fishermen invade the safety area of the platforms. This being so, avoiding safety zones being created during periods of intense fishing activity by transferring passive activities, such as prospecting, to other times of the year is a potentially useful strategy to mitigate these conflicts.

\section{Conclusions}

In addition to biological studies, such as those on species richness, feeding interactions and fish behavior, the attraction the fish feel for the platforms could be an interesting and important subject for social studies, such as that related to the direct conflict between fishermen and oil exploration companies.

The vessels sighted in the area of the Ocean Star oil-drilling platform during the two Exploration Campaigns belonged to artisanal fleets. The characteristics of the vessels differed according to the dominant fishery resource during the sighting period. The dolphinfish fishery is carried out by pelagic longline with vessels longer than $11 \mathrm{~m}$ and registered in the state of Espírito Santo. Inversely, during the skipjack-tuna season, smaller vessels from outside the state of Espírito Santo and with licences to fish for other resources besides dolphinfish are present in the area. In general, the crews showed no concern about using the safety area for their activities (fishing, sailing or anchoring), and did not cooperate with the environmental technicians who attempted to communicate with them.

\section{ACKNOWLEDGEMENTS}

I would like to thank the company Perenco Petróleo e Gás do Brasil Ltda for providing the data obtained during the implementation of the Social Communication Project on the two exploration oildrilling campaigns in the Espírito Santo Basin. 


\section{REFERENCES}

BRONZ, D. Pescadores do petróleo: políticas ambientais e conflitos territoriais na Bacia de Campos, RJ. Rio de Janeiro: E-papers Serviços Editoriais Ltda, 2009. 200 p.

FABI, G.; GRATI, F.; PULETTI, M.; SCARCELLA, G. Effects on fish community induced by installation of two gas platforms in the Adriatic Sea. Mar. Ecol. Progr Ser, v. 273, p. 187-197, 2004.

GIRARD, C.; DAGORN, L.; TAQUET, M.; AUMEERUDDY, R.; PEIGNON, C.; BENHAMOU, S. Homing abilities of dolphinfish (Coryphaena hippurus) displaced from fish aggregating devices (FADs) determined using ultrasonic telemetry. Aquat. Living Resour., v. 20: 313-321, 2007.

JABLONSKI, S. 2003 Interações da pesca com a atividade petrolífera na bacia de Campos, Rio de Janeiro. In: SEMINÁRIO SOBRE MEIO AMBIENTE MARINHO, 4, 2003, Rio de Janeiro. Anais. Rio de Janeiro: Sociedade Brasileira de Engenharia Naval - Sobena, 1921/nov/2003. 15p.

JABLONSKI, S. The interaction of the oil and gas offshore industry with fisheries in Brazil: The "Stena Tay" experience. Braz. J. Oceanogr., v. 56, p. 289-296, 2008.

JORGENSEN, T.; LOKKEBORG, S.; SOLDAL, A. V. Residence of fish in the vicinity of a decommissioned oil platform in the North Sea. ICES J. Mar. Sci., v. 59, p. 288-293, 2002.

KLIPPEL, S.; MARTINS, A. S.; OLAVO, G.; COSTA, P.A.S.; PERES, M.B., Estimativas de desembarque da pesca de linha na costa central do Brasil (estados do Espírito Santo e Bahia) para um ano padrão (1997-2000). In: COSTA, P. A. S.; MARTINS, A. S.; OlAVO, G. (Eds.) Pesca e potenciais de exploração de recursos vivos na região central da Zona Econômica Exclusiva brasileira. Rio de Janeiro: Museu Nacional. p.71-82 (Série Livros n.13) 2005

LOKKEBORG, S.; HUMBORSTAD, O. B.; JORGENSEN, T.; SOLDAL, A. V. Spatio-temporal variations in gillnet catch rates in the vinicity of North Sea oil platforms. ICES J. Mar. Sci., v. 59, p. 294-299, 2002.

MANOUKIAN, S.; SPAGNOLO, A.; SCARCELLA, G.; PUNZO, E.; ANGELINI, R.; FABI, G. Effects of two offshore gas platforms on soft-bottom benthic communities (northwestern Adriatic Sea, Italy). Mar. Envir. Res., v. 70, p. 402-410, 2010.
MARINHA DO BRASIL. NORMAM-08: Normas da Autoridade Marítima para tráfego e Permanência de Embarcações em Águas Jurisdicionais Brasileiras, 8 Diretoria de Portos e Costas-DPC. Marinha do Brasil. 2000

MARTINS, A. S.; DOXSEY, J. R. Diagnóstico da Pesca no litoral do Espírito Santo. In: ISAAC, V.; MARTINS, A. S.; HAIMOVICI, M.; FILHO, J. M. A. A pesca marinha e estuarina do Brasil no início do século XXI: Recursos, tecnologias, aspectos socioeconômicos e institucionais. Belém: Ed. Universitária UFPA, 2006, p. 93-116.

MARTINS, D. S.; BRAGA, R. Contribuição para elaboração de cartas de sensibilidade ambiental para derramamentos de óleo: impactos socioambientais na atividade pesqueira. HOLOS Environment, v. 9, p. 219-235, 2009.

MARTINS, A. S.; OLAVO, G.; COSTA, P. A. S. A pesca de linha de alto mar realizada por frotas sediadas no Espírito Santo, Brasil. In: COSTA, P. A. S.; MARTINS, A. S.; OLAVO, G. Pesca e potenciais de exploração de recursos vivos na região central da Zona Econômica Exclusiva brasileira. Rio de Janeiro: Museu Nacional, 2005, p. 35-55

MENEZES, A.; SANTOS, R.; LIN, C.; VIANNA, M.; NEVES, L. Caracterização das capturas comerciais do bonito-listrado, Katsuwonus pelamis, desembarcado em 2007 no Rio de Janeiro, Brasil. Revista CEPSUL Biodiversidade e Conservação Marinha, v. 1, p. 29-42, 2010.

SILVA, M. H.; SOARES, G. S. S. 2013 Boletim estatístico da pesca do Espírito Santo - Ano 2011: Programa de estatística pesqueira do Espírito Santo. Espírito Santo: Universidade Federal do Espírito Santo, 2013. 94 p.

UNCLOS - United Nations Convention on the Law of the Sea, 1982. Available at: <http://www.un.org/Depts/los/ convention_agreements/convention_overview_conventio n.htm> Accessed in April 2013.

(Manuscript received 15 December 2013; revised 10 October 2014; accepted 20 October 2014) 